\title{
Erratum to: The association between CYP1A1 genetic polymorphisms and coronary artery disease in the Uygur and Han of China
}

\author{
Jin-Guo Zou ${ }^{1,2+}$, Yi-Tong Ma ${ }^{1 *}$, Xiang Xie ${ }^{1,2+}$, Yi-Ning Yang ${ }^{1}$, Shuo Pan ${ }^{1,2}$, Dilare Adi ${ }^{1,2}$, Fen Liu ${ }^{2}$
} and Bang-Dang Chen ${ }^{2}$

Although the focus of our article in Lipids in Health and Disease [1] reports novel data and has a different focus compared to publications in Clinical Biochemistry, Lipids in Health and Disease and Clinical and Applied Thrombosis/Hemostasis [2-5], we acknowledge that we have duplicated some text. We apologize for the inappropriate overlap between our two publications and our lack of transparency about the similarities between these articles.

\footnotetext{
Author details

'Department of Cardiology, First Affiliated Hospital of Xinjiang Medical University, Urumqi 830054, People's Republic of China. ${ }^{2}$ Xinjiang Key Laboratory of Cardiovascular Disease Research, Urumqi 830054, People's Republic of China.
}

Received: 17 September 2015 Accepted: 17 September 2015

Published online: 28 September 2015

\section{References}

1. Zou JG, Ma YT, Xie X, Yang YN, Pan S, Adi D, et al. The association between CYP1A1 genetic polymorphisms and coronary artery disease in the Uygur and Han of China". Lipids Health Dis. 2014;13:145.

2. Zhu Q, Zhenyan F, Yitong $M$, Hong $Y$, Ding $H$, Xiang $X$, et al. A novel polymorphism of the CYP2J2 gene is associated with coronary artery disease in Uygur population in China. Clin Biochem. 2013;46(12):1047-54

3. Adi $\mathrm{D}$, Xiang $\mathrm{X}$, Yi-Tong $\mathrm{M}$, Zhen-Yan F, Yi-Ning $\mathrm{Y}$, Xiao-Mei $\mathrm{L}$, et al. Association of COL4A1 genetic polymorphisms with coronary artery disease in Uygur population in Xinjiang, China. Lipids Health Dis. 2013;12:153.

4. Fu Z, Ma Y, Xie X, Huang D, Yang H, Nakayama T, et al. "A Novel Polymorphism of the CYP4A11 gene is associated with coronary artery disease", Clin Appl Thrombosis/Hemostasis, 2012.

5. Zordoky, Beshay NM, El-Kadi, Ayman OS. "Effect of cytochrome P450 polymorphism on arachidonic acid metabolism and their impact on cardiovascular diseases", Pharmacol Ther, 2010

\footnotetext{
* Correspondence: myt-xj@163.com

'Equal contributors

'Department of Cardiology, First Affiliated Hospital of Xinjiang Medical University, Urumqi 830054, People's Republic of China
}

\section{Submit your next manuscript to BioMed Central and take full advantage of:}

- Convenient online submission

- Thorough peer review

- No space constraints or color figure charges

- Immediate publication on acceptance

- Inclusion in PubMed, CAS, Scopus and Google Scholar

- Research which is freely available for redistribution

Submit your manuscript at www.biomedcentral.com/submit 